EXPERIMENTS TO DETERMINE SENSITIVITY OF NMC GAMMA MONITORS TO

DISTANT FISSION BURSTS

E. C. Crume



prepored for the U.S. ATOMIC ENERGY COMMISSION under U.S. GOVERNMENT Contract W.7405 eng 26 
Reference to a company or product name does not imply approval or recommendation of the product by Union Carbide Corporation or the U.S. Atomic Energy Commission to the exclusion of others that may meet specifications.

This report was prepared as an account of work sponsored by the United States Government. Neither the United States nor the United States Atomic Energy Commission, nor any of their employees, nor any of their contractors, subcontractors, or their employees, makes any warranty, express or implied, or assumes any legal liability or responsibility for the accuracy, completeness or usefulness of any information, apparatus, product or process disclosed, or represents that its use would not infringe privately owned rights. 


\section{EXPERIMENTS TO DETERMINE SENSITIVITY \\ OF NMC GAMMA MONITORS TO \\ DISTANT FISSION BURSTS}

E. C. Crume

December 1974

\section{MASTER}

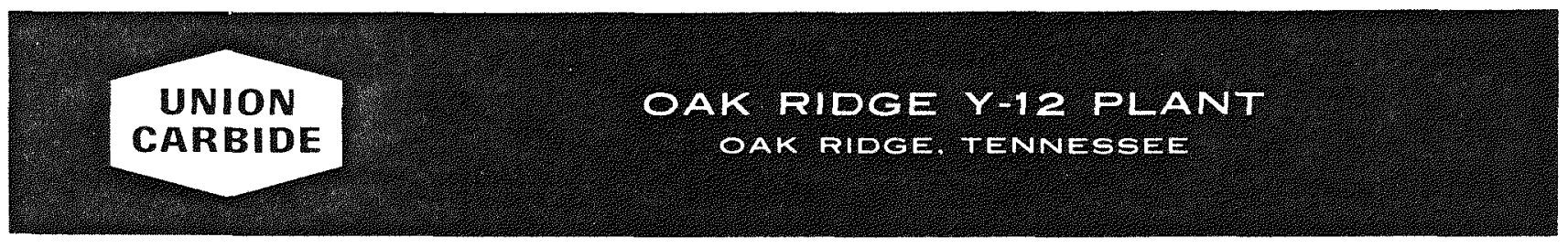

prepared for the U.S. ATOMIC ENERGY COMMISSION under U.S. GOVERNMENT Contract W.7405 eng 26 
Reference to a company or product name does not imply approval or recommendation of the product by Union Carbide Corporation or the U.S. Atomic Energy Commission to the exciusion of others that may meet specifications.

This report was prepared as an account of work sponsored by the United States Government. Neither the United States nor the United States Atomic Energy Commission, nor any of their employees, nor any of their contractors, subcontractors, or their employees, makes any warranty, express or implied, or assumes any legal liability or responsibility for the accuracy, completeness or usefulness of any information, apparatus, product or process disclosed, or represents that its use would not infringe privately owned rights. 


\title{
EXPERIMENTS TO DETERMINE SENSITIVITY OF NMC GAMMA MONITORS TO DISTANT FISSION BURSTS
}

\author{
E. C. Crume \\ Radiation Safety Department \\ Y-12 Technical Division
}

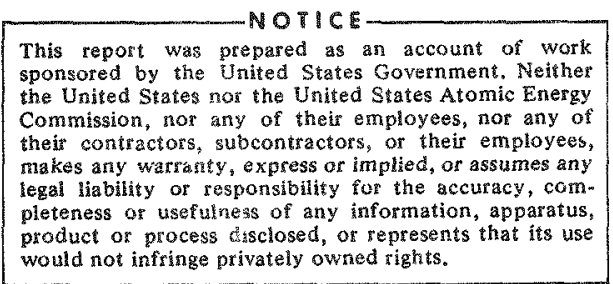

Oak Ridge Y.12 Plant

P.O. Box Y, Oak Ridge, Tennessee 37830

Prepared for the U.S. Atomic Energy Commission Under U.S. Government Contract W-7405eng-26 


\section{EXPERIMENTS TO DETERMINE SENSITIVITY OF NMC GAMMA MONITORS TO DISTANT FISSION BURSTS}

In February and March 1967, experiments were run both at the Oak Ridge National Laboratory (a) and the Oak Ridge Critical Experiments Facility (ORCEF) at the Oak Ridge Y-12 Plant.(a) In these experiments, from one to four calibrated Nuclear Measurements Corporation (NMC) gamma detectors with built-in trip points were located from 1000 to 1100 feet from prompt burst reactors. The NMCs were calibrated in the calibration facility at $Y$-12. They were operated from either gasoline generators or truck-mounted 110-volt generators for both the tests and calibrations. Because the NMCs used did not have latching-trip relays, a latching-trip box containing four such relays was built and used in these tests. Bursts having fission yields ranging from $7.13 \times 10^{14}$ to $1.3 \times 10^{17}$ were observed in these experiments. The full width at half maximum of the bursts ranged from a few hundred microseconds to approximately 3 milliseconds. Results of the experiments are given in Table 1.

The main results and inferences from the experiments are summarized as follows:

1. A burst of $7.13 \times 10^{14}$ fissions caused a trip at a setting of $50 \mathrm{mr} / \mathrm{hr}$ on an NMC located $\sim 1000$ feet from the burst (2/16/67 HPRR burst). Only incidental shielding from trees and air was between the HPRR and NMC.

2. For burst magnitudes increasing from $2 \times 1016$ to $1.3 \times 1017$ fissions, only about a $10 \%$ increase in NMC readings was observed, and most of this increase occurred between $2.0 \times 1016$ and $2.9 \times 1016$ fissions. This difference is a consequence of the decreased width of the major part of the pulse; ie, as the fission yield rises, most of the fissions occur during a shorter time.

3. Based on steady-state measurements at the location of the NMC for the HPRR tests(b) (see Figure 1 and Table 2), the gamma dose rate per $\mathrm{kW}$ of reactor power is $4 \mathrm{mrem} / \mathrm{hr}$. Assuming that the $7.13 \times 10^{14}$ fission burst occurred in $1 \mathrm{msec}$, and using a conversion of $3 \times 1010$ fissions $/ \mathrm{kW}$ msec, an equivalent steady power of $2.38 \times 10^{4} \mathrm{~kW}$ was obtained. Thus, the dose rate at the NMC during the burst was $9.51 \times 10^{4} \mathrm{mrem} / \mathrm{hr}$. Assuming that the NMC would not have read higher than its trip point of $50 \mathrm{mrem} / \mathrm{hr}$, the NMC was only $50 / 9.51 \times 10^{4} \simeq 1 / 1900$ as sensitive as ideal detection. Alternatively, the $9.66 \times 1015$ HPRR burst which tripped a meter at a $750 \mathrm{mr} / \mathrm{hr}$ setting was considered. The equivalent steady power here would be $3.22 \times 105 \mathrm{~kW}$, yielding a dose rate of $1.29 \times 106 \mathrm{mrem} / \mathrm{hr}$. Assuming that the NMC would not have read higher than its trip point of $750 \mathrm{mrem} / \mathrm{hr}$, the NMC was only $750 / 1.29 \times 106 \simeq 1 / 1700$ as sensitive as

(a) Facilities operated by the Union Carbide Corporation's Nuclear Division for the US Atomic Energy Commission.

(b) Intra-Laboratory Correspondence-ORNL; September 16, 1965. 
Table 1

TABULATION FOR NMC RESPONSE TESTS

(February - March 1967)

\begin{tabular}{|c|c|c|c|c|c|}
\hline Date & Location(1) & $\begin{array}{l}\text { Burst Size } \\
\text { (fissions) }\end{array}$ & $\begin{array}{l}\text { Full Width } \\
\text { or Half Maximum } \\
\text { (ms) }\end{array}$ & $\begin{array}{l}\text { Tripped at Trip } \\
\text { Settings of: }\end{array}$ & Comments \\
\hline $2 / 16 / 67$ & HPRR Site & $7.13 \times 10^{14}$ & & 50, but not 500 & \\
\hline $2 / 21 / 67$ & $1000 \mathrm{ft}$ from HPRR & $9.66 \times 10^{15}$ & 1.0 & $50,300,500,750$ & \\
\hline $2 / 23 / 67$ & $\begin{array}{l}\text { ORCEF Site, }>1100 \mathrm{ft} \\
\text { from APR; } \sim 1 \mathrm{ft} \\
\text { Concrete Cell } \\
\text { Shielding }\end{array}$ & $8.7 \times 10^{15}$ & & $5,10,15,100$ & \\
\hline $2 / 23 / 67$ & Same as $2 / 23 / 67$ Test & $2.0 \times 10^{16}$ & & 50, but not 500 & \\
\hline $2 / 24 / 67$ & Same as $2 / 23 / 67$ Test & $2.0 \times 10^{16}$ & & $\begin{array}{l}50, \text { but not } 300 \text {, } \\
\text { Although an Observed } \\
400 \text { Pegged but did } \\
\text { not Latch }\end{array}$ & $\begin{array}{l}550 \mathrm{mr} / \mathrm{hr} \text {, read on } 5000 \text { scale of one instrument. Between } 10-26 \\
\mathrm{mr} / \mathrm{hr} \text { at various buildings on other side of hill in } Y-12 \text { main area. }\end{array}$ \\
\hline $2 / 24 / 67$ & Same as $2 / 23 / 67$ Test & $2.9 \times 10^{16}$ & 0.6 & 50 , but not 1000 & $\begin{array}{l}600 \mathrm{mr} / \mathrm{hr} \text {, read on } 5000 \text { scale on one instrument and } 550-600 \mathrm{mr} / \mathrm{hr} \\
\text { on scale of another. Same range on instruments in } Y-12 \text { main area as for } \\
\text { previous shot. }\end{array}$ \\
\hline $2 / 25 / 67$ & Same as $2 / 23 / 67$ Test & $3.6 \times 10^{16}$ & & 50, but not 650 & $\begin{array}{l}600 \mathrm{mr} / \mathrm{hr} \text {, read on } 5000 \text { scale of one instrument and } 550 \mathrm{mr} / \mathrm{hr} \text { on } \\
1000 \text { scale of another. Approximately same range of readings in } \gamma-12 \\
\text { area as before. }\end{array}$ \\
\hline $2 / 28 / 67$ & Same as $2 / 23 / 67$ Test & $\begin{array}{l}4.2 \times 10^{16} \text { to } \\
1.3 \times 10^{17}\end{array}$ & & & $\begin{array}{l}\text { Little if any increase in NMC readings over previous shots, starting with } \\
2 \times 10^{16} \text { yield. }\end{array}$ \\
\hline $3 / 17 / 67$ & $\begin{array}{l}\text { Same HPRR Location } \\
\text { as Before }\end{array}$ & $1.03 \times 10^{16}$ & 0.9 & & $\begin{array}{l}\text { Recorder trace from fast recorder has a spike of } \Delta=25 \text { units, but } \\
\text { generator was failing. }\end{array}$ \\
\hline $3 / 17 / 67$ & In HPRR Area & $2.3 \times 10^{16}$ & $\begin{array}{l}3 \mathrm{~ms}(?) \text { (more likely } \\
0.75 \mathrm{~ms} \text { ) }\end{array}$ & & $\begin{array}{l}\text { Recorder trace of } \Delta=29 \text { units; generator steady. Calibration note, } \\
3 / 19 / 67: \text { A steady field of } 1.2 \mathrm{r} / \mathrm{hr} \text { from a calibration source gave a meter } \\
\text { reading of } 700 \mathrm{mr} / \mathrm{hr} \text { and a recorder trace of } 37.5 \text {. This calibration is for } \\
\text { the } 3 / 17 / 67 \mathrm{HPRR} \text { run only. Earlier calibrations of NMRs for HPRR } \\
\text { and APR shots were much closer to the actual readings. }\end{array}$ \\
\hline
\end{tabular}

(1) HPRR- ORNL Health Physics Research Reactor

APR - Aberdeen Pulse Reactor 


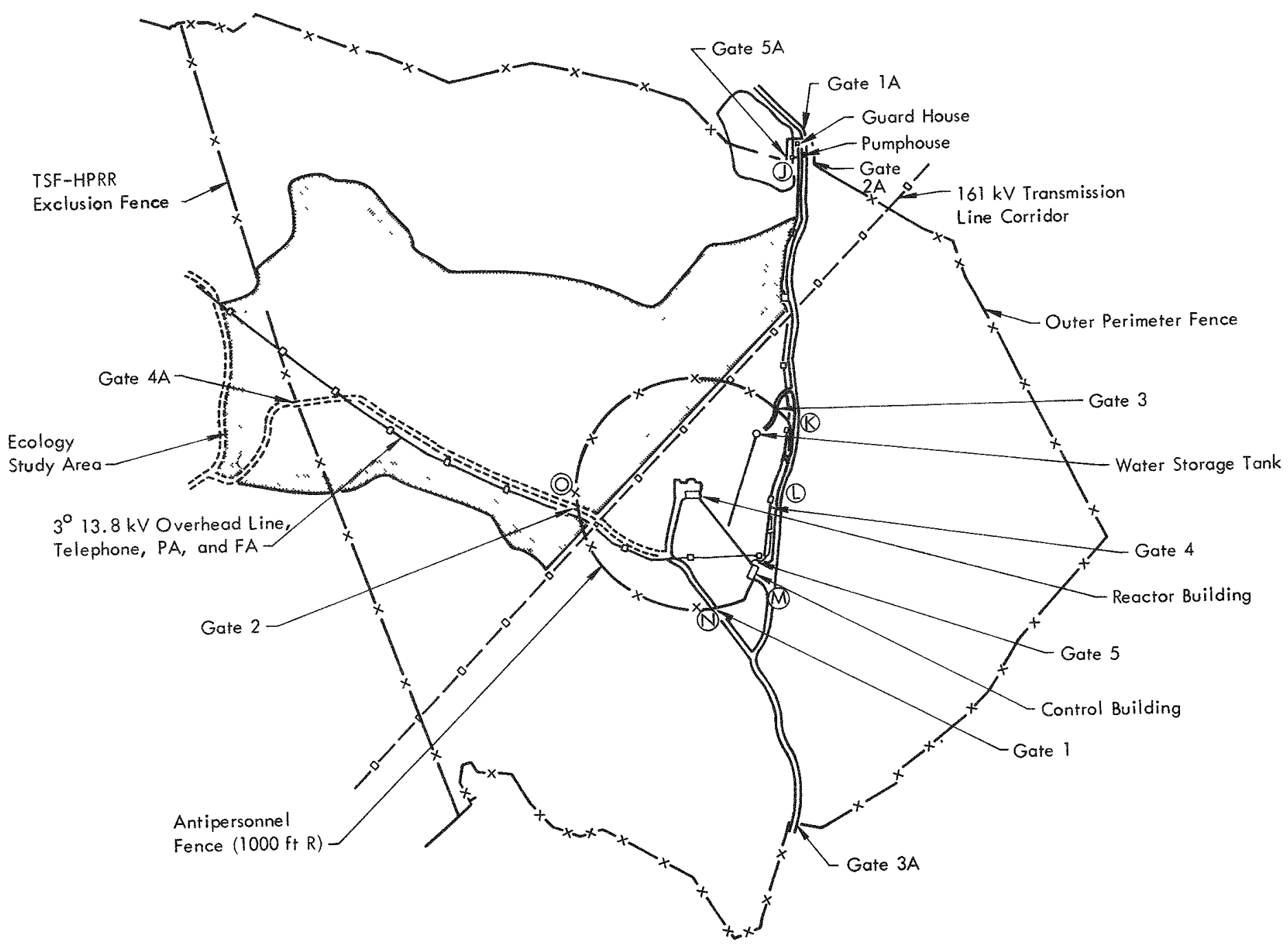

Figure 1. PLOT PLAN OF THE DOSAR FACILITY EXCLUSION AREA. 
Table 2

DOSE RATES AT SELECTED POINTS WITHIN THE HPRR 3000-FT EXCLUSION AREA

\begin{tabular}{|c|c|c|c|c|}
\hline \multirow[b]{2}{*}{ Position } & \multicolumn{4}{|c|}{ Dose Rate $(\mathrm{mrem} / \mathrm{hr} / \mathrm{kW})$} \\
\hline & Gamma Rays & $\begin{array}{l}\text { Thermal } \\
\text { Neutrons }\end{array}$ & $\begin{array}{c}\text { Fast } \\
\text { Neutrons }\end{array}$ & Total Dose \\
\hline \multicolumn{5}{|c|}{ Inside Control Building } \\
\hline A & 0.6 & 1.9 & 0.4 & 2.1 \\
\hline B & 0.7 & 0.9 & 1.3 & 2.9 \\
\hline c & 0.5 & 0.6 & 0.4 & 1.5 \\
\hline D & 0.5 & 0.6 & 0.7 & 1.8 \\
\hline$E$ & 1.4 & 1.7 & 3.1 & 6.2 \\
\hline$F$ & 0.03 & 0.01 & 0.03 & $<0.1$ \\
\hline G & 0.5 & 0.6 & 0.4 & 1.5 \\
\hline$H$ & 0.5 & 0.6 & 0.4 & 1.5 \\
\hline 1 & 0.9 & 1.3 & 4.0 & 6.2 \\
\hline \multicolumn{5}{|c|}{ Outside Control Building } \\
\hline J & 0.02 & 0.01 & 0.05 & $<0.1$ \\
\hline K & 3 & 4 & 30 & 37 \\
\hline L & 7 & 10 & 90 & 107 \\
\hline M & 4 & 6 & 50 & 60 \\
\hline $\mathbf{N}$ & 3 & 3 & 40 & 46 \\
\hline O (NMC Location) & 4 & 5 & 60 & 69 \\
\hline
\end{tabular}

the ideal detection. In both of these exarnples, the meter readings would undoubtedly have been higher; but, due to HPRR site regulations, it was not possible to have an observer present. The crude calibration attempt on March 17, 1967 gives about 550 $\mathrm{mrem} / \mathrm{hr}$ which, assuming a burst yield of $2.3 \times 10^{16}$ fissions, gives a sensitivity of only $550 / 3.07 \times 106 \simeq 1 / 5600$, if it is assumed that the burst was on a $1-\mathrm{msec}$ time scale, or $\simeq 1 / 1860$ if on the 3-msec time scale. This calculation shows the sensitivity decreasing with power, as was the case for the Aberdeen Pulse Reactor (APR) shots, but there is no interest in the sensitivity at the high end of the scale. Rather, the interest lies in the low end, as in the $7.13 \times 10^{14}$ fission example where it is seen that the sensitivity is at least $1 / 1900$ of the steady-state value. Consequently, an arbitrarily selected value of $1 / 2500$ is conservative with respect to the experimental results. 


\section{DISTRIBUTION}

Allied Chemical - Idaho

Fraser, R. J.

Morrison, W. G.

Atomic Energy Commission - New York

McLaughlin, J. E.

Atomic Energy Commission - Oak Ridge

Johnson, E. B.

McLendon, J. D. (10)

Mee, W. T.

Wilkinson, P. E.

$Y-12$ Central Files (5)

$Y-12$ Central Files (master copy)

Y-12 Central Files (route copy)

Johnson, W. A.

$Y-12$ Central Files ( $Y-12 R C)$

Atomic Energy Commission - Washington

Ketzlach, N. (regulatory)

McQuire, S. A. (OSHA)

Stevenson, R. L.

Babcock and Wilcox

Alcorn, F. M.

Battelle, Northwest - Richland

Clayton, E. D.

Dow - Rocky Flats

Schuske, C. L.

General Electric - Washington

Dawson, D. M.

Goodyear Atomic - Portsmouth

Woltz, F. E.

Los Alamos Scientific Laboratory

Paxton, H. C.

Smith, D. R.

National Lead of Ohio

Dunaway, D. L.

Oak Ridge National Laboratory

Thomas, J.T.

Crume, E. C.

Oak Ridge $Y-12$ Plant

Denny, A. (3) 